\title{
Policy and Tourism Development Strategy towards Tourist Friendly Destination in Kuala Lumpur
}

\author{
Ahmad Nazrin Aris Anuar ${ }^{1,2}$, Habibah Ahmad ${ }^{2}$, Hamzah Jusoh $^{2} \&$ Mohd Yusof Hussain $^{2}$ \\ ${ }^{1}$ Centre of Studies Park \& Amenity Management, Faculty of Architecture, Planning \& Surveying, Universiti \\ Teknologi MARA, Shah Alam, Malaysia \\ ${ }^{2}$ School of Social, Development and Environment, Faculty of Social Sciences and Humanities, National \\ University of Malaysia, Bangi, Malaysia \\ Correspondence: Ahmad Nazrin Aris Anuar, Centre of Studies Park \& Amenity Management, Faculty of \\ Architecture, Planning \& Surveying, Universiti Teknologi MARA, Shah Alam, Selangor Darul Ehsan, Malaysia. \\ Tel: 60-35-521-1544. E-mail: aek_2751@yahoo.com
}

Received: October 31, 2012 Accepted: November 19, 2012 Online Published: January 28, 2013

doi:10.5539/ass.v9n2p180 URL: http://dx.doi.org/10.5539/ass.v9n2p180

The research is financed by Ministry of Higher Education Malaysia, Universiti Teknologi MARA and National University of Malaysia.

\begin{abstract}
A tourist friendly destination is a concept that gives satisfaction to tourists through contact and the maximum utilization dimensions of space, activities, and products; without any interruptions or problems. Accordingly, this study aims to describe the tourism policy and strategies in national and state contexts, to determine the inherent direction and prospects or potential in the tourism development of Kuala Lumpur as a tourist-friendly destination. The results show that some aspects need to be emphasized and have similarities in each of policies and strategies at the national and state level. This shows that policies made at national level could be followed at state level, so that each line of tourism development planning should be as planned. However, there is currently no planning policy at a national level, only at a state level. This shows that the policy at state level will continue with added value, made from reforms in accordance with the current situation and the existing physical characteristics, not run away with the principle of a planned policy at national level. Accordingly, in Kuala Lumpur, no problems or obstacles exist to planned, managed and developed, through the concept of being a Tourist Friendly City, where it is in line with the requirements of tourism development policies and strategies of national and state levels.
\end{abstract}

Keywords: national and state levels, tourism development strategy, tourism policy, tourist friendly destination

\section{Introduction}

Tourism is one of the largest and most important industries today. It developed after the decline of manufacturing and several other industries, which were previously monopolized by the world's economic and social system (Iversen \& Wren, 1998; Mc Intosh, Goeldner \& Ritchie, 2000; Mohamed, 2005). With development, tourism destinations should be more creative and unique, in order to produce a competitive tourism destination (Anuar et al., 2012a). Hence the introduction of a tourist friendly destination concept is seen as being capable of promoting tourism destinations to tourists as a customer-oriented concept (Anuar et al., 2012b). This concept is needed to ensure supply in the tourism industry and to consistently meet the demands of tourists. In Malaysia, to realize that tourism can contribute to the progress of the country and play a role in its economic and social development, the Malaysian government began to take a positive approach to developing the tourism industry more seriously. Development of the tourism industry in Malaysia can be seen through increased physical developments, such as infrastructure, facilities, marketing and promotion (Anuar et al., 2012c). Malaysia's seriousness about the tourism industry is reflected in the planning and tourism development in the Malaysia Five-Year Plan (MP), starting at MP1 to MP10; supplemented with National Tourism Policy (NTP) and the latest is Economic Transformation Programme (ETP) at national level. In addition, to see Kuala Lumpur as the center of attraction, as well as as an urban tourism promotion in Malaysia's tourism industry, Kuala Lumpur was chosen as a case study. Thus, the Kuala Lumpur Tourism Policy, Tourism Development Strategy of Kuala Lumpur, Kuala Lumpur Structure Plan 
2020, and Kuala Lumpur City Plan 2020, are seen as the basis for policy and strategy for tourism developments at state level. Even though Kuala Lumpur is seen as a catalyst to the development of the tourism industry, increasing revenue and generating higher returns through higher-dimensional space; activities and products in the tourism industry have further transformed Malaysia's tourism industry from a low yield to high yield. Accordingly, this study describes the development of Malaysia's tourism planning policy at national and state levels, and aims to determine the existing and potential direction and prospects that may exist, in determining the formation and development of a tourist friendly destination concept in Kuala Lumpur.

\section{Policies and Tourism Development Strategies at National Level}

The policies and strategies of tourism development are also planned through the Malaysia Five-Year Plan. Starting with MP1, in an effort to consolidate and promote the tourism industry, so that it continues to grow and develop on par with other international destinations. Thus, the Malaysia Five-Year Plan is seen to directly affect the NTP as a basis and guide in the development of the tourism industry, as well as the development of the concept of a tourist friendly destination in Malaysia. In addition, the added value of the tourism industry is also responsible in the ETP, through National Key Economic Area (NKEA)-Tourism, to continue to propel the country towards a higher income and status in the year 2020.

\subsection{Malaysia Five Year Plan}

Tourism planning and development in Malaysia is considered important, so that Malaysia can continue to compete in the regional; especially with other ASEAN countries. The seriousness of Malaysia's tourism development can be seen through a five-year plan showing every aspect of Malaysia; which has always emphasized tourism as an important source of national income. Accordingly, the strategy of tourism development in Malaysia has always enacted accordance with the Five Year Plan so all tourism plans are reached. Tourism was given prominence starting from the MP6 until to date-MP10. The following in Table 1.0 are the highlights of each MP6 to MP10 in terms of tourism development (Pejabat Perdana Menteri Malaysia, 2012).

Table 1. National tourism development strategy in Malaysia's five year plan

\begin{tabular}{cl}
\hline MP & \multicolumn{1}{c}{ National Tourism Development Strategy } \\
\hline MP6 & $\begin{array}{l}\text { - Bring together and channel investment into the region and selected activities, with a potential to } \\
\text { generate tourism growth; especially in terms of increasing employment opportunities, income, added } \\
\text { value, and linkages with other economic sectors. This strategy has been to provide the necessary support } \\
\text { to promote locally and internationally. }\end{array}$
\end{tabular}

MP7 - Diversify products and services to meet the various demands and interests of local and international

1996 tourists, to reduce the dependence on network infrastructure products and limited tourism. Apart from marketing the natural beauty, cultural and historical heritage of Malaysia, new product development will focus on the promotion of this country as a destination for shopping, sports, conventions, and a special appeal in connection with travel and water based activities.

- Ensure more effective promotion and marketing to local and overseas markets.

- To encourage investment and private sector participation in innovative tourism products, projects, and special events.

- Increase the involvement of local communities; especially small entrepreneurs, in the development of tourism products and services, with their own unique characteristics.

- Identify and provide infrastructure and basic facilities.

- Improve and provide communication facilities to enter the country. Steps will be taken to further enhance connectivity to the country and states.

MP8 - To emphasize sustainable development (i.e., the balance between economic, social, cultural, and

2001 environmental aspects in all planning and implementation of tourism activities). Conservation of the physical environment and cultural heritage, which is a tourism product that is a main attraction and a sensitive asset to be preserved with care; including natural parks, rivers, lakes, caves, wetlands, and wildlife protection areas.

- Focusing on a holistic approach in tourism development (innovation and strength of the private sector, hospitality, courtesy and civic consciousness amongst the public and the government, to support and develop the tourism industry).

- Display Malaysia as an attractive destination with a carnival atmosphere throughout the year.

- Implement the development and promotion of products that focus on customers by creating cruise and yatching tourism. 
- Provide and enhance the communication network.

- To ensure comfort, safety, and the well-being of tourists.

MP9 - To ensure sustainable tourism development.

2006 - Improve product development and innovative tourism services.

- Encourage and facilitate domestic tourism.

- To encourage marketing and promotional activities.

- Focus on new product developments, such as eco-tourism, agro-tourism, cultural tourism, and heritage tourism, meetings and exhibitions, sports and recreational tourism, educational tourism, and Malaysia My Second Home.

MP10 - Improve the image of tourism destinations.

2011 - Focus on the state's tourism development direction, based on the nine core areas of eco-tourism, heritage tourism, homestay tourism, coastal and island tourism, sports tourism, meetings and exhibition tourism, golf tourism, food tourism, shopping, and health tourism.

- Create major tourist events and large-scale programmes leading to improved levels of safety, cleanliness, comfort, and develop tourism facilities and infrastructure.

- Enhance and continue the marketing and promotion of intensive tourism products to countries in key markets in Asia, Europe, and Indo-China.

- Give emphasis on improving the quality of training and human resource development, to ensure that their role in this industry can deliver quality services.

Sources: Pejabat Perdana Menteri Malaysia (2012)

\subsection{National Tourism Policy}

National Tourism Policy (NTP) has been designed to be implemented over a period of 10 years. NTP works to elevate the tourism industry as being strong, sustainable, viable, sustainable, and competitive; and to make it a main contributor to the economy. Thus, the main objectives of the NTP are to (Hamzah, 2004):

1) Generate foreign policies

2) Encourage equitable economic and social development

3) Promote rural entreprise

4) Generate employment

5) Accelerate rural/urban integration and cultural exchange

6) Encourage the participation of various ethnic communities in the tourism sector

7) Create and improve image of Malaysia internationally

8) Forge national unity

NTP has provided a long-term direction for the planning, development, and marketing of the tourism industry in Malaysia. First came the presence of the marketing concept of sea, sand, and sun, but then the NTP brought us a new era in the development of tourism products such as fly-drive holidays, riverine tourism, ecotourism, agrotourism, culture and heritage based tourism, Meetings, Incentives, Conferences \& Exhibitions (MICE) and special interest tourism (Hamzah, 2004). In fact, the NTP has also recommended promoting Malaysia as a tourist shopping paradise, especially through the Mega Sale Carnival tag line. This clearly shows that significant reforms in the tourism industry are based on the strength and resources of existing tourism products and images.

\subsection{Economic Transformation Programme}

Economic Transformation Programme (ETP) is a program run by the Performance Management and Delivery Unit (PEMANDU) to drive economic development towards transforming Malaysia into a high income country by 2020. ETP has identified 12 NKEAs in which the tourism sector ranked fifth in the NKEAs priority list. Tourism in NKEA refers to both leisure and business tourism, and includes the following subsectors: lodging, shopping, tourism products (i.e., eco-tourism, cruise tourism, and other related activities, such as spa and wellness), food and drink and state (inbound) and domestic transportation. Medical education is not included in this NKEA, because it will be addressed in another NKEA Laboratory (PEMANDU, 2012).

The main purpose of the ETP in the tourism sector is to increase the contribution of Gross National Income (GNI) of RM67 billion to reach RM104 billion in 2020, from RM37 billion in 2009. This shows that the tourism sector needs to improve GNI three times from its starting position in 2009 (PEMANDU, 2012). Additional 
improvement was driven by 12 Entry Point Project (EPP), which acted to deliver RM28.4 billion, and three business opportunities that would provide RM28.6 billion in the additional GNI. Furthermore, during the implementation of the EPP, 497,000 additional jobs will be created in Malaysia (PEMANDU, 2012). Therefore, to increase the amount of national income through tourism, tourist's expenditure and length of stay in Malaysia are amongst the strategies, by targeting 36 million tourists and RM168 billion received revenue from tourists by 2020. A total of 12 EPPs, categorized into six themes, and supported by the three business opportunities and 4 public variables, can provide these returns over the next 10 years. The placement of 12 EPP through six themes in ETP-NKEA Tourism are shown in Table 2.0 (PEMANDU, 2012).

Table 2. Matrix placement of 12 epp through six themes in nkea tourism

\section{Theme}

\begin{tabular}{l} 
EPP \\
Positioning Malaysia as a duty-free shopping destination for tourist \\
goods \\
Designating Kuala Lumpur City Centre (KLCC)-Bukit Bintang area as \\
a vibrant shopping precinct \\
Establishing three new premium outlets in Malaysia \\
Establishing Malaysia as a global biodiversity hub \\
Developing an eco-nature integrated resort in Sabah \\
Creating Straits Riviera \\
Targeting more international events \\
Establishing dedicated entertainment zone \\
Developing local expertise and better regulating the spa industry better \\
Expanding sports tourism offering in Malaysia, beyond hosting events \\
Establishing Malaysia as a leading business tourism destination \\
Enhancing connectivity to priority medium-haul markets \\
Improving rates, mix and quality of hotels \\
\hline Sourcs: PEMANDU (2012)
\end{tabular}

Sources: PEMANDU (2012)

To achieve these targets, financing of RM204 billion is needed over the next 10 years. Thus, in realizing the potential of the tourism sector, four variables (which are widespread and important to each sector in the sectoral plan), are to increase and focus on marketing in the major tourist markets, reintroduce selective visa on arrival, ensure the provision of adequate qualified human capital, and ultimately, improve the tourism environment to develop supply and access (such as taxi services), and access to funding and quality of frontline staff (PEMANDU, 2012). All variables are seen as significant in driving the country to a high income country by 2020.

\section{Policies and Tourism Development Strategies at State Level}

The focus of tourism development is on policies and strategies, especially those contained in the Kuala Lumpur Structure Plan 2020 and the Kuala Lumpur City Plan 2020, which are the two most important documents in the planning and physical development of the tourism sector in Kuala Lumpur. Reference to these two sources is 
necessary to know and describe the tourism policy and tourism development strategy Kuala Lumpur, which will be applied in these cities. Therefore, the following description will look at how the development of tourism in Kuala Lumpur as a major tourist destination can be translated and the relationship to the formation and development of a tourist-friendly destination concept in Kuala Lumpur.

\subsection{Kuala Lumpur Tourism Policies}

Kuala Lumpur's position as the nation's main city should be maintained in the long run. This is because the city of Kuala Lumpur will continue to strive to remain competitive in Malaysia, over others such as Iskandar Malaysia, Northern Corridor Economic Region, and the Eastern Corridor Economic Region (Dewan Bandaraya Kuala Lumpur, 2011), in obtaining international and domestic tourist arrivals. Accordingly, the Kuala Lumpur tourism policy was formulated through Dewan Bandaraya Kuala Lumpur (DBKL) as local authority, to accelerate the development of tourism in the state, to be more effective and controlled in accordance with the goals and strategies of tourism development at a national level. Under the Kuala Lumpur tourism policy, some policies have been outlined (Dewan Bandaraya Kuala Lumpur, 2012):

1) DBKL will market and promote tourism in Kuala Lumpur.

2) DBKL will develop tourism products aimed at expanding and diversifying the tourism base.

3) DBKL will ensure the development of tourism products depicting nation's identity and image of a multi-ethnic, religious and cultural society.

4) DBKL will implement a zonal approach to tourism development in the city.

5) DBKL will actively promote, encourage, and facilitate arts and cultural activities at local and international levels.

6) DBKL will designate the historic urban core as the main cultural heritage centre of the nation and diversify the cultural infrastructure so as to ensure there is a critical mass of attractions.

7) DBKL will coordinates with the private sector to promote Kuala Lumpur as an international shopping, dining and entertainment destination.

8) DBKL will provide and develop opportunities for eco-tourism in the forests reserve and other suitable hilly areas.

9) DBKL will join other agencies and relevant authorities, promote major sports complexes as venues for international sports and other events.

10) DBKL will join other organizations and medical institutions, to develop and promote educational and health care tourism.

11) DBKL will promote a diversification of accommodation modes.

12) DBKL will promote Kuala Lumpur as an international meetings, incentives, conventions and exhibitions; and encourage the development of suitable facilities.

13) DBKL together with the Kuala Lumpur Tourism Action Council, will coordinate with relevant agencies and the private sector to develop a supporting information system for tourists.

14) DBKL will provides training programmes and support information to tourist front-liners.

15) DBKL will coordinate with agencies and relevant authorities to ensure that all major tourist attractions area are provided with high quality facilities and well maintained facilities.

\subsection{Kuala Lumpur Tourism Development Strategies}

The Kuala Lumpur tourism development strategy intends to enhance its role as a center of international trade and finance. Accordingly, DBKL will act as the party responsible for developing Kuala Lumpur as an attractive international tourist destination, and increase the average period of stay (ALS) to 3.0 nights (Dewan Bandaraya Kuala Lumpur, 2012). In addition, to create a city that has its own identity and image, DBKL must continue to look after the environment, architecture, and cultural heritage, by offering a strong combination of modern and traditional features.

Even DBKL is also promotional activities, arts and culture, sports, education, and health, as a major tourism product; along with other factors to improve the overall quality of life in creating a tropical garden city, which are sensitive to nature and appropriate to the location of this tropical region (Dewan Bandaraya Kuala Lumpur, 2012). Accordingly, some of the strategies underlying the development of tourism in the City of Kuala Lumpur are as follows (Dewan Bandaraya Kuala Lumpur, 2012): 
1) Tourism marketing and promotion

2) Development of tourism resources

3) Shopping, dining and entertainment

4) Recreational attractions

5) Health and education

6) Tourism facilities and infrastructure

7) Tourism support services and facilities

\subsection{Kuala Lumpur Structure Plan 2020}

As the capital and a leading city of Malaysia's based trading economy, which aims to become a developed nation by 2020, the vision, goals, and functions of Kuala Lumpur City Centre should be seen in the context of a broad global perspective; especially in the context of growth in the Asia-Pacific region. Vision 2020 has identified globalization as a major mega trend that must be followed by Malaysia, to guarantee a solid foundation of economic development. However, as the premier city in Malaysia, it must adopt a strong global orientation. This means industry and services with a high export potential are required to provide the impetus towards globalization. The entry of skilled and high-tech industries, financial services, transportation, tourism, business and professional information, shopping and commercial activities are seen as major components of economic growth, and must be developed quicker than at present (Dewan Bandaraya Kuala Lumpur, 2012).

Accordingly, the vision of Kuala Lumpur City Centre developments should always be consistent and reflect Vision 2020. Thus, the city of Kuala Lumpur's vision is "Kuala Lumpur - A World Class City," to provide benefits and ensure that infrastructure, environment, urban management, cultural facilities, society and the community meet the high expectations of the population, workers, visitors and the investors (Dewan Bandaraya Kuala Lumpur, 2012). Thus, the Kuala Lumpur Structure Plan 2020 was established by the Federal Territory Act (Planning) of 1982 (Act 267) to serve as a guide to policy makers, urban planners, property developers and others, in planning and developing Kuala Lumpur towards being a World Class City. The Kuala Lumpur Structure Plan 2020 contains details of relevant components in the formation of the City's economic base and population, land use and development strategies, trade, tourism, industry, transport, infrastructure and utilities, housing, community facilities, urban design and landscape, environment, and other specific areas.

Each component is described to provide an integrated city, which is to function efficiently and progressive (Dewan Bandaraya Kuala Lumpur, 2012). Accordingly, in planning and developing Kuala Lumpur towards being a World Class City, five main objectives of the Kuala Lumpur Structure Plan 2020 were identified, namely (Dewan Bandaraya Kuala Lumpur, 2012):

1) First goal - To enhance the role of Kuala Lumpur as an international commercial and financial centre

2) Second goal - To create an efficient and equitable city structure

3) Third goal - To enhance the city living environment

4) Fourth goal - To create a distinctive City identity and image

5) Fifth goal - To have an efficient and effective governance

It was found that the tourism industry in Kuala Lumpur has emphasized the implication of two goals; the third goal of improving the living environment and the fourth goal of creating an identity and image of their own city. The Kuala Lumpur Structure Plan 2020 has clarified that the tourism industry has played an important role in the economy of Kuala Lumpur to contribute income, employment opportunities, and the expansion of business opportunities. The tourism industry also accounts for a wide area of services and facilities needed in providing employment opportunities for local people and tourists. In addition, the existence of the tourism industry in Kuala Lumpur continues to benefit conservation projects, beautification, and pedestrian walkways, as well as hosting special events and festivals designed to attract international and domestic tourists. A pleasant climate and unique tropical characteristics, an infrastructure and services sector, as well as a variety of tourist attractions, shopping facilities, entertainment, hotels and conference venues, supplemented with various ethnic groups, religions and cultures, has created an identity and image to make Kuala Lumpur an international tourist destination (Dewan Bandaraya Kuala Lumpur, 2012).

\subsection{Kuala Lumpur City Plan 2020}

As identified in the Kuala Lumpur Structure Plan 2020, the heart of Kuala Lumpur's vision is 'A World Class 
City', where it will play a global role. Positive changes to the physical environment should be implemented without compromising the environment. Thus, DBKL and local authorities need to ensure that planning is carried out to achieve a balance between physical, economic, social, and environmental issues. Therefore, the Kuala Lumpur City Plan 2020 was drafted as a planning framework for the next 12 years, and creates a basis to achieve the development's vision by 2020. This plan is a guide that encourages planning and sustainable development by giving priority to three main aspects of environmental quality, social equity, and economic prosperity

These aspects were placed into the main framework of the draft KL City Plan 2020 to encourage innovative solutions in land development, whilst controlling the intensity of activities to move towards being a World Class City. As a World Class City, Kuala Lumpur plans to develop a quality living environment, taking into account the physical and social developments of sustainable, balanced, economic activity, fair and efficient administration, the provision of public facilities and a minimum level of quality of life, such as ensuring access to infrastructure, a clean environment, affordable housing, green fields, and the opportunity to have a regular competitive life. In the face of global challenges, establishing more competitiveness in the city, DBKL should look at Malaysia Plans, particularly the Ninth and Tenth, as a national program to maintain urban development and strategies in the City Plan 2020.

Accordingly, the Kuala Lumpur City Plan 2020 identified projects and programs to be undertaken during the period of this plan. To achieve that vision, this plan has been translated into four mechanisms of implementation, namely the management mechanism, control mechanisms of planning, marketing mechanism, and sharing mechanism. Planning the direction of travel in Kuala Lumpur is closely related to the growth of economic activity that will strengthen the role of Kuala Lumpur as the largest employment center that concentrates on its business activities, banking, retail, tourism, and culture. Therefore, this study demonstrates that the city tourism of Kuala Lumpur, as well as being an international tourism destination, focuses on specific tourism products and offers a lifestyle destination in an international environment. Thus, various initiatives have been taken to establish Kuala Lumpur as a world-class tourist destination city (Dewan Bandaraya Kuala Lumpur, 2011):

1) Kuala Lumpur as a tourist-friendly city

2) Increase the number of MICE facilities

3) Introduce Kuala Lumpur as a regional center for tourism education

4) Enhance the heritage tourism

5) Develop sports and recreation facilities to strengthen local tourism.

International and domestic tourism is seen as a key player in Kuala Lumpur's success, where it will drive the group of economic activities and factors that drive the local economy. Therefore, the services sector in Kuala Lumpur should be strengthened to meet the demand and experience needed by tourists. The services sector in Kuala Lumpur covers the entire range of wholesale and retail activities, restaurants and hotels (e.g., shopping, food, and accommodation), transport, storage, and communication (e.g., car rentals, taxis, travel agencies, tour operators, airlines, shipping, bus services, etc.), banking, insurance, real estate, and business services (e.g., banking, foreign exchange, insurance, and real estate development), and community, social and personal services (e.g., tour guides, drivers, operators of food and small service providers) (Dewan Bandaraya Kuala Lumpur, 2011).

The Kuala Lumpur City Plan 2020 will focus on specific tourism products, such as MICE, medical tourism, and education, where it has the potential to be developed. In addition, attention should be given to the tourism products available, such as shopping, culture, heritage, and parks for tourism activities. Hence, the particular proposals made in the draft Kuala Lumpur City Plan 2020 to meet the tourist industry in Kuala Lumpur are (Dewan Bandaraya Kuala Lumpur, 2011):

1) Tourist friendly City

2) As a medical tourism sector developing competitivenes in Kuala Lumpur

3) Introducing a Kuala Lumpur regional centre for tourism as education

4) Enhance the City heritage tourism activities

5) Develop sports and recreation to strengthen local tourism

\section{The Findings and Discussion}

\subsection{Policy Review}

Based on these policies and strategies, tourism development at national and state levels has been stated, and it 
can be concluded that the development of tourism in Kuala Lumpur is more based on the concept of urban tourism resources to be developed into a tourist destination, and being able to attract more areas of tourists; especially from international and domestic tourists, but not limited to the current market areas i.e., students and researchers. A summary of policies and strategies for tourism development in Kuala Lumpur can be seen in Table 3.0. This summary clearly shows that several aspects should be emphasized with similarities between each of the policies and strategies at both national and state levels. This shows that policy could be made at the national level, followed by the next policy and implementation strategies at state level; so that each line of tourism development is as planned.

However, there is no planning policy at national level, just at state. This shows that policy at state level will continue to add value and make reforms in accordance with the current situation and physical characteristics; but, it will not run with the original principles, as planned at the national level. Meanwhile, there are several aspects of the policy at national and state levels that should be emphasized and considered important in explaining the planning and development of tourism in Kuala Lumpur.

Table 3. Summary of policy and related aspects

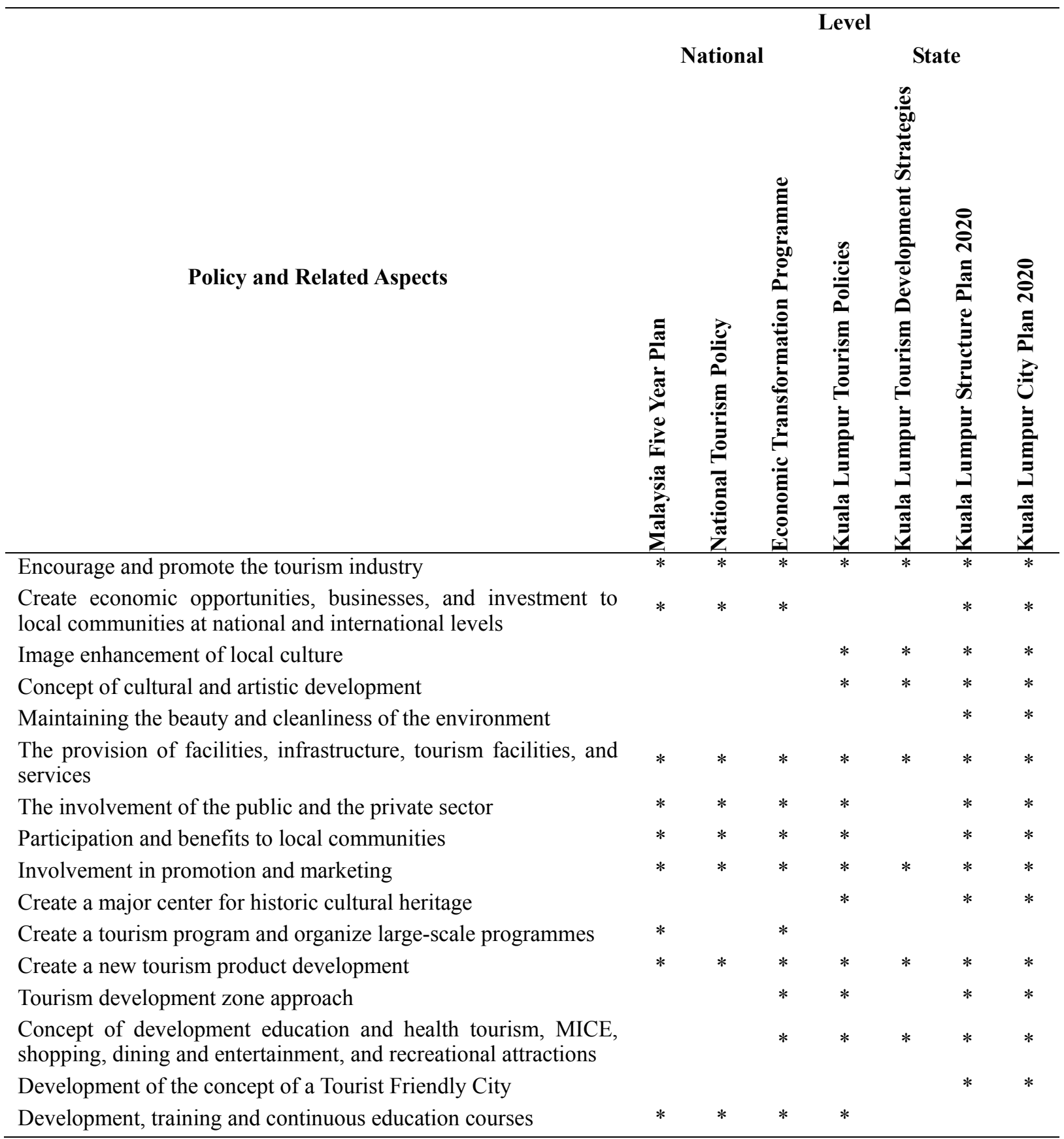




\subsection{The Positioning Of Tourist Friendly Destination Concept in Kuala Lumpur}

Policies at national and state levels, identifying the concept of Kuala Lumpur as a tourist-friendly destination were referred to in the Kuala Lumpur Structure Plan 2020, and were explained in detail in the draft Kuala Lumpur City Plan 2020. For example, planning and tourism development in Malaysia has focused on the provision of facilities, infrastructure services, creating programs and activities and the involvement of tourism for the use of tourists. This shows that the dimensions of space, activities, and products, has been developed and implemented for the purpose of conceiving a tourist-friendly destination.

At state level, the Kuala Lumpur Structure Plan 2020 implicitly emphasized two main objectives, with the aim of improving the living environment of the third and fourth goals of creating an identity and image of their own city. These two goals stressed that the tourism industry on the development of a new Kuala Lumpur through the provision of a wide area of services, shopping facilities, entertainment, hotels and conferences, the emphasis on conservation projects, beautification and pedestrian walkways, to host special events and festivals designed to attract international and domestic tourists, to make Kuala Lumpur an international tourist destination. Hence, it is a component of the basic concept of a tourist-friendly destination. Meanwhile, in the draft Kuala Lumpur City Plan 2020, the concept of a tourist-friendly destination in Kuala Lumpur was called a 'tourist-friendly city', and the strategies undertaken to implement this concept would be through the addition, repair and upgrading of space considerations, activities, and products that are available in Kuala Lumpur. This would not only be needed for the local community, but also for use by tourists to meet the required demand. The effect is that tourists will stay in Kuala Lumpur for a longer time. In this regard, Kuala Lumpur's initiative to realize this concept of a tourist-friendly city includes (Dewan Bandaraya Kuala Lumpur, 2011):

1) Creating tourist centers in strategic locations to provide tourist information and guides.

2) Encourage the private sector to open gift shops that are integrated with the visitor centers and encourage the establishment of user-friendly information kiosks.

3) Encourage the opening of local travel agencies around the visitor center to help foreign tourists, as well as to create a network of cooperation between the Tourist Information Centre and tour agencies. This would be done in an effort to centralize travel agencies in Kuala Lumpur, so that price adjustments can be made.

4) Upgrading of all signs and the addition of important information on signs to guide tourists; especially along Jalan Ipoh, Jalan Sentul, Jalan Kuching, and Jalan Kepong MRR2.

5) Upgrade and beautify tourist areas in the city center, by adding street furniture and amenities to create a safe and barrier-free environment.

6) Identification of parking and special tourist bus attractions.

7) Public transportation, such as adequate buses and taxis.

8) Provide tourist police to assist tourists and ensure that the city is always safe. Tourist police booths can be placed in the tourist attractions of Bukit Bintang, Jalan Sultan Ismail, Jalan Petaling, Jalan Pasar Seni, and Alor in Kuala Lumpur City Centre.

9) Maintain all public toilets on an ongoing basis, including those in private buildings, such as shopping malls, museums, and galleries.

10) Getting the power to determine bus routes "hop-on hop-off" to ensure effective and affordable fares.

11) Support the tourist market by promoting the development of budget travel facilities and hotels (bed and breakfast) in the City Centre, Damansara, Penchala, and around the Brickfields area. Carry out the redevelopment of obsolete programs in tourism zones.

12) Allow change of use, for heritage buildings and buildings that are not used, into boutique hotels, bed and breakfasts, etc; especially in the City Centre and Damansara area (i.e., Penchala).

13) Adding large-scale MICE facilities to meet the needs of activities, exhibitions, and international conferences. Propose a new MICE facility to be developed at the Government Complex in Jalan Duta.

14) Improving and upgrading existing sports facilities, such as the Bukit Jalil Sports Complex, Stadium Merdeka, and Stadium Negara.

The Kuala Lumpur Structure Plan 2020 and the draft Kuala Lumpur City Plan 2020 clearly shows that the placement of tourist-friendly destination concept has been proposed to be implemented in Kuala Lumpur where it reflects a combination of infrastructure, superstructure, facilities, services, hospitality, activities, marketing, and promotions, to meet the demands of tourists. These combinations represent the essential elements underlying 
formation of tourist friendly destination concept (Anuar et al., 2012d). In fact, it can be proven that when the supply of tourism in Kuala Lumpur is seen as something that is unique in a complex combination of tourism services, resources (environmental, natural, man-made: made up from the sun, landscape, culture, and amenities), infrastructure, facilities, and experience. This was evident in a study by Swarbrooke (1995), which stated that tourists tend to respond well to tourist-friendly attractions; where tourists are looking for convenience and service, and travel time can be saved from residential homes to the tourist destination. Thus, tourists would be happy to travel to a Kuala Lumpur that is an all-dimensional friendly space, where activities and products can be used easily and without problem.

\section{Conclusion}

Policies related to Kuala Lumpur at the national level emphasize the promotion of the tourism industry in the development of physical, social, and economic factors. This is due to the existence of an active tourism industry in Kuala Lumpur, and economic opportunities, enhanced trade, and investment, will provide opportunities and benefits to local communities. Even creating core-based tourism products, such as eco-tourism, sports, heritage, meetings and exhibitions, golf, food and shopping, and health tourism, are seen as a stepping stone to providing the dimensional space, activities, and products of international class nations that have already implemented the concept of city tourism, such as Manchester, London, Glasgow, Paris, Bradford, etc. By providing space dimension, activities, and products, indirectly introduces the concept of a tourist-friendly destination in Kuala Lumpur. In addition, policy at state level emphasizes the need to develop Kuala Lumpur as a tourist destination city that projects an image and culture. In addition, the upgrading and improvements needed in the dimensions of space, activities, and products, such as the provision of facility components, infrastructure, facilities, and available services; in addition to the activity, safety, cleanliness, and comfort of tourists, was also discussed and requires the cooperation of all stakeholders involved. This is because the dimensions of space, activities, and product components, provide the foundation for the concept of a tourist-friendly destination, as proposed for Kuala Lumpur. Hence, the introduction of this concept; especially in Kuala Lumpur, is essential, because tourists will choose their own space, activities and products, if they can meet the demands and experience desired. In fact, the need to apply the concept of a tourist-friendly destination in Kuala Lumpur is caused by the development of Kuala Lumpur itself, which now functions as a main attraction. Therefore, it should not be a problem for Kuala Lumpur to be planned, managed, and developed through the concept of a tourist-friendly destination, as a Tourist Friendly City; which will be in line with the requirements of tourism development policies and strategies for Kuala Lumpur.

\section{References}

Anuar, A. N. A., Ahmad, H., Jusoh, H., \& Hussain, M. Y. (2012a). Understanding the factors influencing formation of tourist friendly destination concept. Journal of Management and Sustainability, 2(1), 106-114. http://dx.doi.org/10.5539/jms.v2n1p106

Anuar, A. N. A., Ahmad, H., Jusoh, H., \& Hussain, M. Y. (2012b). The roles of tourism system towards development of tourist friendly destination concept. Asian Social Science, 8(6), 146-155. http://dx.doi.org/10.5539/ass.v8n6p146

Anuar, A. N. A., Ahmad, H., Jusoh, H., \& Hussain, M. Y. (2012c). Understanding the role of stakeholder in the formation of tourist friendly destination concept. Journal of Management and Sustainability, 2(2), 69-74. http://dx.doi.org/10.5539/jms.v2n2p69

Anuar, A. N. A., Ahmad, H., Jusoh, H., \& Hussain, M. Y. (2012d). The essential elements underlying formation of tourist friendly destination concept: Analysis in micro level. Asian Social Science, 8(13), 59-70. http://dx.doi.org/10.5539/ass.v8n13p59

Dewan Bandaraya Kuala Lumpur (DBKL). (2011). Draf Pelan Bandar Raya Kuala Lumpur 2020. Retrieved September 30, 2011, from http://klcityplan2020.dbkl.gov.my/sme/

Dewan Bandaraya Kuala Lumpur (DBKL). (2012). Pelan Struktur Kuala Lumpur 2020. Retrieved July 24, 2012, from http://www.dbkl.gov.my/pskl2020/malay/index.htm

Hamzah, A. (2004). Policy and planning of the tourism industry in Malaysia. Proceeding The 6th. ADRF General Meeting, 2004 Bangkok, Thailand, 1-21.

Iversen, T., \& Wren, A. (1998). Equality, Employment and Budgetery Restraint: The Trilemma of the Service Economy. World Politics, 50(4), 507-546. http://dx.doi.org/10.1017/S0043887100007358 
McIntosh, R. W., Goeldner, C. R., \& Ritchie, J. R. W. (2000). Tourism: Principles, practices, philosophies (8th ed.). New York: Wiley.

Mohamed, B. (2005). The analysis of Malaysian domestic travelers. Proceeding of International Conference on Tourism Development, 373-381.

Pejabat Perdana Menteri Malaysia. (2012). Rancangan Malaysia. Retrieved July 4, 2012, from http://www.pmo.gov.my/?menu=page\&page=2005

PEMANDU. (2012). Program Transformasi Ekonomi-Pelancongan. Retrieved August 4, 2012, from http://etp.pemandu.gov.my/Tourism-@-More_on_Tourism.aspx?lang=ms-my

Swarbrooke, J. (1995). The Development and Management of Visitor Attractions. London: Butterworth Heinemann. 